\title{
Calix[4]pyrroles Bearing Pyrene-pickets at Diametrical Meso-positions with Amide Linkage ${ }^{\dagger}$
}

\author{
Jaeduk Yoo, In-won Park, Tae-Young Kim, and Chang-Hee Lee ${ }^{*}$ \\ Department of Chemistry and Institute of Molecular Science \& Fusion Technology, Kangwon National University, \\ Chun-Chon 200-701, Korea. ${ }^{*}$ E-mail: chhlee@kangwon.ac.kr \\ Received January 18, 2010, Accepted January 21, 2010
}

\begin{abstract}
The synthesis and ion binding properties of calix[4]pyrrole bearing pyrene moieties appended to one side of the calix [4]pyrrole are reported. The key feature is the presence of flexible fluorescence arms attached to the calix[4]pyrrole ring in a cis-fashion. The preliminary solution phase anion and cation binding studies revealed that the systems can be in fact as viable sensors for anionic guest.
\end{abstract}

Key Words: Calix[4]pyrrole, Fluorophore appended, Chemosensors, Pyrene, CHEF

\section{Introduction}

Synthetic receptors which are capable of selective binding and recognition of anionic substrates are of great interest due to the importance of anions in various fields of studies including environmental science and biology. ${ }^{1-6}$ The design and synthesis of anion receptors possessing high affinity and selectivity still remains a challenging task due to rather complex nature of anionic species compared with those of cations. Among the various neutral anion receptors reported in recent years, calix[4] pyrroles and their congeners have emerged as particularly attractive, in part because they are readily accessible and can be obtained in single step from commercially available starting materials. Various modified calix[4]pyrroles have been designed and synthesized for improved recognition properties. ${ }^{7-13}$ Among them, calix[4]pyrroles bearing diametrical strap on one side of the macrocycle (A) have attracted attention due to their superior binding properties. ${ }^{14-18}$ In contrast to most other calixpyrrole derivatives, these systems allow for a pre-organization of the binding domain, a feature that has allowed for a fine-tuning of their selectivity and affinity. Unlike the calix[4]arenes, the calix[4] pyrroles are more flexible and undergo conformational changes easily. The conversion from the 1,3-alternate conformation to a bowl-like cone conformation can occur simply binding with anions. The spatial orientation of the meso-substituents also undergoes a dramatic change as a consequence of anion binding.

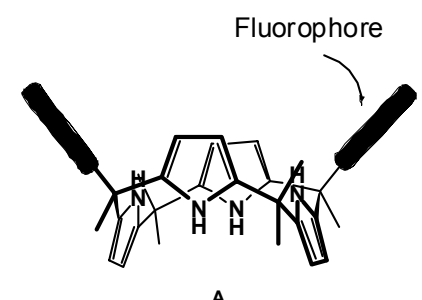

Scheme 1. Schematic representation of calix[4]pyrrole attached with fluorophores at meso-position

${ }^{\dagger}$ This paper is dedicated to Professor Sunggak Kim on the occasion of his honorable retirement.
If two or more fluorophores, such as pyrene, are introduced at the meso-positions of the calix[4]pyrrole, the conformational motion could potentially be used to change the fluorescence properties of the molecule. This effect, which could be potentially exploited to produce chemosensor activity, should be enhanced when auxiliary hydrogen bonding donor sites are introduced into the linker arm. Because the effects are largely conformation-based, the systems should give rise to greater substrate-induced changes in fluorescence than rather rigid systems that were reported earlier. ${ }^{19-21}$ In fact, unlike these previous pyrene-functionalized systems, as well as the various other calix[4] pyrrole-based sensor systems reported to date, ${ }^{22-23}$ systems based on conformation-based changes in the orientation of chromophores are expected to combine directly an anion binding event with a fluorescence change. In this paper we report the synthesis and ion binding properties of calix[4]pyrroles bearing pyrene moieties appended to one side of the calix[4]pyrrole. We also report the results of preliminary solution phase anion and cation binding studies and show that the systems in question can in fact as viable sensors. As detailed below, in these systems ancillary functional groups have been incorporated into the linker arm in order to gauge the effect, in any, that changes in the linker have on the system as a whole.

A key feature incorporated into the proposed receptors is the presence of flexible arms that strap the calix[4]pyrrole ring in a cis-fashion. As shown in Scheme 1, 4-hydroxyacetophenone 1 was condensed with pyrrole to afford corresponding dipyrromethane 3 , which was condensed with acetone to give mixture of calix[4]pyrrole 5 and its isomer 7 in $26 \%$ and $2 \%$ yields, respectively. The two isomers were easily separated by column chromatography on silica. Then, the compound $\mathbf{5}$ was coupled with pyrene derivative 9 to afford the desired receptor 10 in $12 \%$ yield. When 3 -hydroxyacetophenone 2 was condensed with pyrrole, dipyrromethane 4 was fomed in $65 \%$ yield. Then, the condensation of $\mathbf{4}$ with acetone afforded a mixture of calix [4]pyrrole 6 and its isomer 8 in 19\% and $15 \%$ yields, respectively. The rest of the synthetic sequences were identical as for the synthesis of those of 10. The isolated yield of receptor 11 was $48 \%$. The identity of the target compounds and intermediates were confirmed by spectroscopic analysis including ${ }^{1} \mathrm{H}$ NMR spectro- 

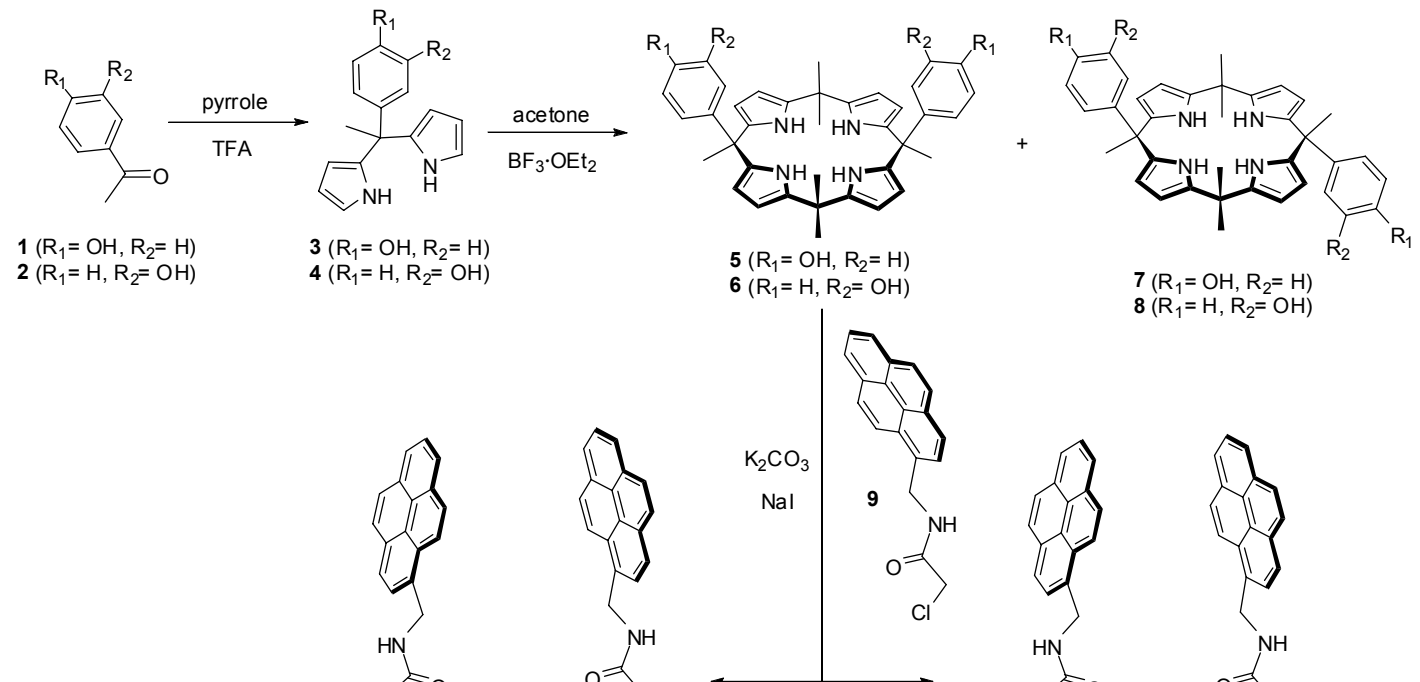

$7\left(\mathrm{R}_{1}=\mathrm{OH}, \mathrm{R}_{2}=\mathrm{H}\right)$
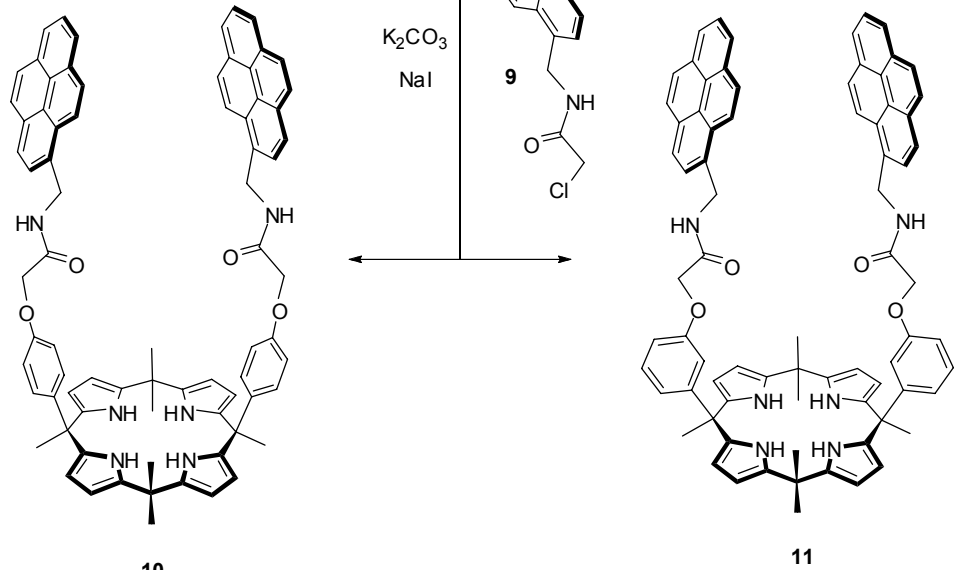

Scheme 2. Synthesis of receptor $\mathbf{1 0}$ and $\mathbf{1 1}$
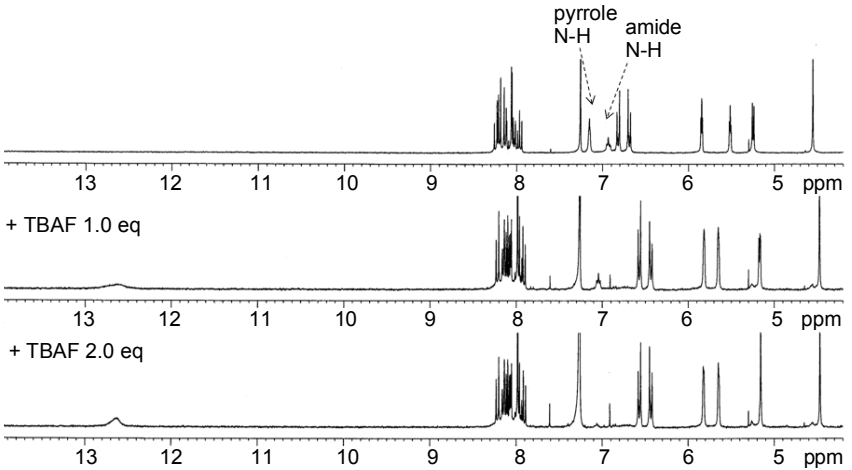

Figure 1. Titration of receptor $\mathbf{1 0}$ with fluoride anion (as its tetrabutylammonium salt $)$ in $\mathrm{CDCl}_{3} .([\mathbf{1 0}]=0.35 \mathrm{mM})$. Top trace is free host.

\section{scopy and HRMS}

Preliminary fluoride anion binding studies of systems $\mathbf{1 0}$ and 11 were carried out in DMSO- $d_{6}$ using proton NMR spectroscopy (Figure 1 and Figure 2). This was done by titrating receptor $\mathbf{1 0}$ or 11 with fluoride anion (studied in the form of its tetrabutylammonium salt). A completely new sets of signals was observed upon the addition of one equivalent of fluoride anion. This observation is consistent with a $1 / 1$ binding stoichiometry and consistent with rather slow complexation/decomplexation kinetics.

When compound $\mathbf{1 0}$ was titrated with fluoride anion, the pyrrole $\mathrm{N}-\mathrm{H}$ proton signals appearing originally at $7.15 \mathrm{ppm}$ in the absence of fluoride anion were shifted to $12.62 \mathrm{ppm}$ as a broad signal in the presence of fluoride anion. On the other hand, signal of the amide N-Hs was almost intact with slight down-

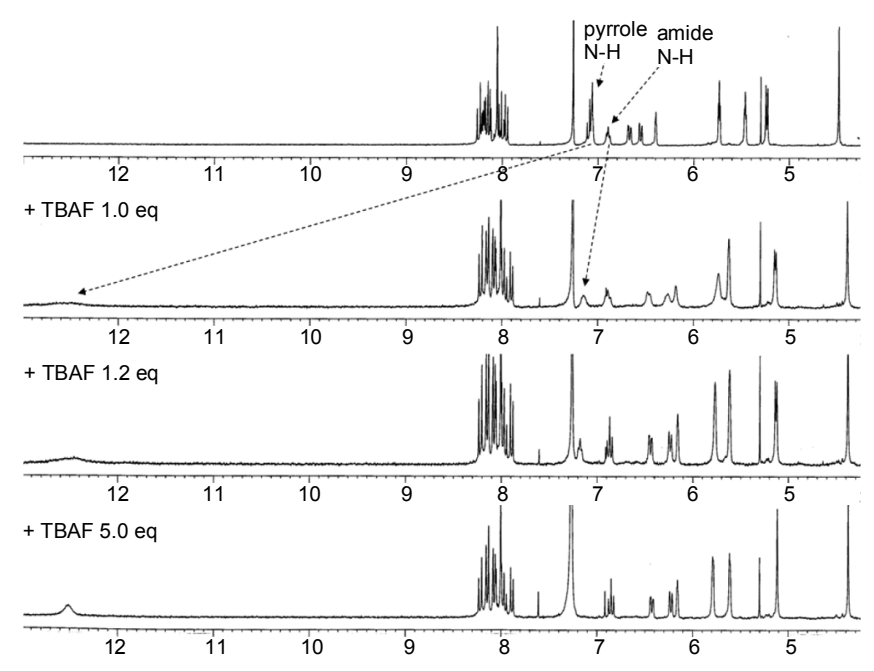

Figure 2. Titration of receptor 11 with fluoride anion (as its tetrabutylammonium salt $)$ in $\mathrm{CDCl}_{3}$. $([\mathbf{1 1}]=0.35 \mathrm{mM})$. Top trace is free host.

field shift (Figure 1). The aromatic protons on the picket were up-field shifted from $6.75 \mathrm{ppm}$ to $6.49 \mathrm{ppm}$, indicating a strongly association of bound anion with aromatic $\pi$-system. Based on these observations, we concluded that the fluoride anion bound to the cavity. The amide N-Hs seemed not to participate in the initial fluoride anion binding and all the experimental observations corresponds to the cavity binding of fluoride anion and the host-fluoride anion complex formation did not lead to the significant spatial changes between the two pyrene units (vide infra).

The titration of receptor $\mathbf{1 1}$ with fluoride anion also showed 


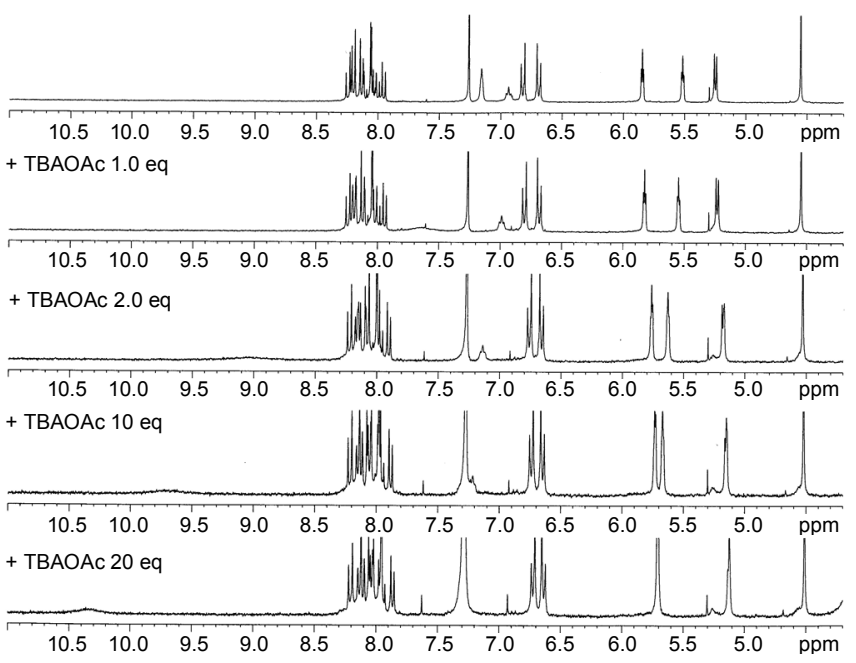

Figure 3. Titration of receptor $\mathbf{1 0}$ with acetate anion (as its tetrabutylammonium salt $)$ in $\mathrm{CDCl}_{3}$. $([\mathbf{1 1}]=0.35 \mathrm{mM})$. Top trace is free host.

similar spectral changes as shown in Figure 2. A completely new set of signals were observed upon the addition of only one equivalent of fluoride anion. This observation is consistent with a $1 / 1$ binding stoichiometry with slow complexation/decomplexation kinetics. However, the resonances of the aryl-Hs were somewhat shifted to up-field but not as large as those of receptor 10. The amide N-Hs seemed not to participate in the initial fluoride anion binding.

It is worth to note that the receptor $\mathbf{6}$ also displays slow complexation/decomplexation binding equilibrium when titrated with fluoride anion unlike meso-octamethyl calix[4]pyrrole. The anion must prefer to bind within the pocket generated by the two aryl groups and the bound-anion mainly interacts with pyrrole N-Hs and weakly interacts with aromatic $\pi$-system.

Titration of receptor 10 with acetate anion studied in the form of its tetrabutylammonium salt gave similar results as those observed with fluoride anion (Figure 3). The signals of the pyrrole $\mathrm{N}-\mathrm{Hs}$ were gradually shifted from $6.94 \mathrm{ppm}$ to $7.21 \mathrm{ppm}$ upon titration with acetate anion. Relatively lower affinity is obvious and indicates the fast complexation/decomplexation kinetics. Unlike the fluoride anion binding, the signals of the Ar-Hs were not shifted. These observations indicate that the acetate anion primarily interact with pyrrole $\mathrm{N}-\mathrm{Hs}$ and amide $\mathrm{N}-\mathrm{Hs}$ with weak hydrogen bonding.

To obtain insight for the fluorescence responses of the receptors with anions, the receptor $\mathbf{1 0}$ was titrated with fluoride anion. As shown in Figure 4, the addition of fluoride anion resulted in decrease in intensities on both the pyrene monomer and excimer bands. The relatively high emission band for both monomer and eximer in $\mathbf{1 0}$ indicates the flexible nature of conformation. The calculated affinity for fluoride anion was $1.1 \times 10^{5} \mathrm{M}^{-1}$ with 1:1 binding stoichiometry. Titration with chloride anion with $\mathbf{1 0}$ displayed similar fluorescence changes as those of fluoride anion. However, slightly larger binding affinity was obtained $\left(\mathrm{K}=3.2 \times 10^{5} \mathrm{M}^{-1}\right)$. These results indicate that the anions mainly interact with pyrrole $\mathrm{N}-\mathrm{Hs}$ and no significant conformational changes of pyrene moieties are accompanied with the binding event. The bound-anion interact weakly with benzene and poss-

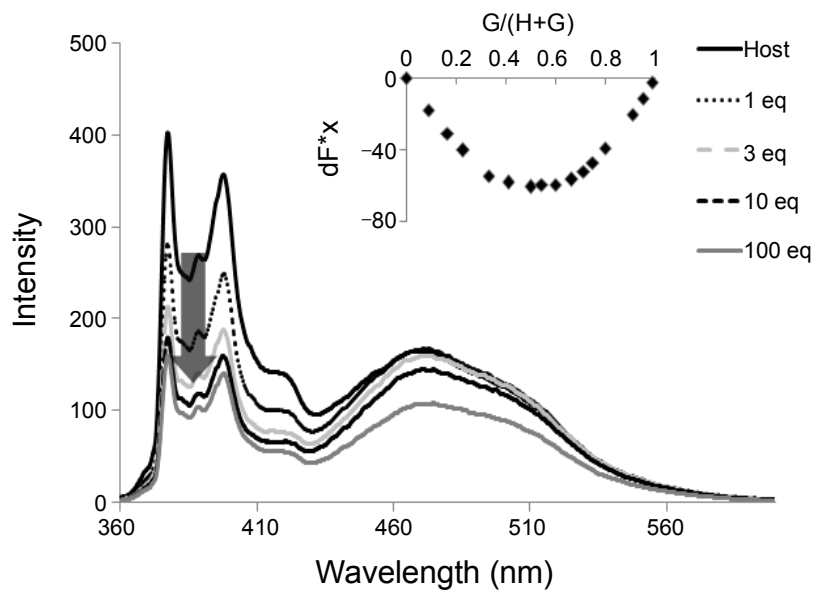

Figure 4. Fluorescence spectral changes upon addition of $\mathrm{F}^{-}$(as its tetrabutyl ammonium salt). [10] $=8.87 \times 10^{-7} \mathrm{M}\left(\mathrm{CH}_{2} \mathrm{Cl}_{2}\right) . \lambda_{\mathrm{ex}}=354$ nm.

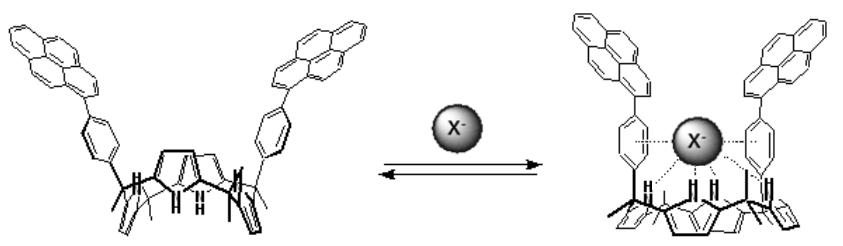

Figure 5. Proposed binding mode with chloride or fluoride anion.

ibly amide N-Hs. The decrease in the fluorescence intensity is merely due to the heavy atom effect or intramolecular CT from anion to pyrene.

In conclusion, we have synthesized and fully characterized calix[4]pyrroles bearing two fluorescent pyrenyl groups at the diametrical meso-positions on one side of the calix[4]pyrrole. Anion-binding studies indicate that fluoride and chloride anion irreversibly binds to the pocket generated by the two pyrene pickets and the affinity for other anions is far less than those of fluoride anion resulting fast complexation/decomplexation kinetics. The conformational changes associated with anion binding are not significant to incur any interaction between the two appended pyrene units. The observed higher affinity of chloride anion other than fluoride anion may be associated with stronger anion-pi interaction in the chloride complex with receptor 10. New model systems bearing tight linkages between pyrene and calix[4]pyrrole are currently under study.

\section{Experimental}

Proton NMR spectra (400 MHz) were recorded using TMS as the internal standard. High and Low resolution FAB mass spectra were obtained on an AUTO SPEC M-363 high-resolution mass spectrometer. Column chromatography was performed over silica gel (Merck, 230 - 400 mesh). Pyrrole was distilled at atmospheric pressure from $\mathrm{CaH}_{2}$. All other reagents were obtained from Aldrich and used as received unless noted otherwise.

5-(4-Hydroxyphenyl)-5-methyldipyromethane (3). To the mixture of 4-hydroxyacetophenone $(4.9 \mathrm{~g}, 0.036 \mathrm{~mol})$, pyrrole 
$(25 \mathrm{~mL})$ was added trifluoroacetic acid $(2.8 \mathrm{~mL})$ at $0{ }^{\circ} \mathrm{C}$ and the mixture was stirred for $72 \mathrm{hr}$ at room temperature. The reaction was quenched by adding aqueous $\mathrm{NaOH}(0.1 \mathrm{~N})$ and extracted with $\mathrm{CH}_{2} \mathrm{Cl}_{2}$ The organic layer was dried $\left(\mathrm{Na}_{2} \mathrm{SO}_{4}\right)$ and the solvent was removed in vacuo. The resulting dark brown solid was purified by column chromatography on silica $\left(\mathrm{CH}_{2} \mathrm{Cl}_{2} / \mathrm{EtOAc}=\right.$ 9/1). Yield : $3.9 \mathrm{~g}(42 \%) ;{ }^{1} \mathrm{HNMR}\left(300 \mathrm{MHz}, \mathrm{CDCl}_{3}\right) \delta 7.78$ (bs, 2H, N-H), 7.01-6.96 (m, 2H, Ar-H), 6.75-6.70 (m, 2H, Ar-H), 6.68-6.66 (m, 2H, $\beta$-pyrrole-H), 6.18-6.15 (m, 2H, $\beta$-pyrrole-H), 5.97-5.95 (m, 2H, $\beta$-pyrrole -H), 4.66 (s, 1H, OH), 2.02 (s, 3H, $\left.\mathrm{CH}_{3}\right)$.

5-(3-Hydroxyphenyl)-5-methyldipyrromethane (4). To the mixture of 3-hydroxyacetophenone $(0.1 \mathrm{~g}, 0.75 \mathrm{mmol})$, pyrrole $(1 \mathrm{~mL})$ was added trifluoroacetic acid $(28 \mu \mathrm{L})$ and the mixture was stirred for $30 \mathrm{~min}$ at $60{ }^{\circ} \mathrm{C}$. The reaction was quenched by adding aqueous $\mathrm{NaOH}(0.1 \mathrm{~N})$ and extracted with $\mathrm{CH}_{2} \mathrm{Cl}_{2}$. The organic layer was dried $\left(\mathrm{Na}_{2} \mathrm{SO}_{4}\right)$ and the solvent was removed in vacuo. The resulting dark brown solid was purified by column chromatography on silica $\left(\mathrm{CH}_{2} \mathrm{Cl}_{2} / \mathrm{EtOAc}=9 / 1\right)$. Yield: $0.12 \mathrm{~g}$ $(65 \%) ;{ }^{1} \mathrm{HNMR}\left(300 \mathrm{MHz}, \mathrm{CDCl}_{3}\right) \delta 7.79$ (bs, $2 \mathrm{H}$, pyrrole-NH), $7.16(\mathrm{t}, J=7.93 \mathrm{~Hz}, 1 \mathrm{H}, \mathrm{Ar}-\mathrm{H}), 6.74-6.70$ (m, 2H, Ar-H), 6.686.66 (m, 2H, $\beta$-pyrrole-H), 6.54-6.53 (m, 1H, Ar-H), 6.19-6.16 (m, 2H, $\beta$-pyrrole-H), 6.00-5.97 (m, 2H, $\beta$-pyrrole-H), 4.66 (s, $1 \mathrm{H},-\mathrm{OH}), 2.03$ (s, 3H, $\left.\mathrm{CH}_{3}\right)$.

5,15-(4-Hydroxyphenyl)-5,10,10,15,20,20-hexamethylcalix [4]pymole (5) and (7). To the mixture of (3) $(0.99 \mathrm{~g}, 3.9 \mathrm{mmol})$, acetone $(400 \mathrm{~mL})$ was added $\mathrm{BF}_{3} \cdot \mathrm{OEt}_{2}(1 \mathrm{~mL})$ and the mixture was stirred for $1 \mathrm{hr}$ at room temperature. The reaction then was quenched upon addition of triethyl amine $(2.4 \mathrm{~mL})$. Excess acetone was removed under reduced pressure and the mixture was combined with water and extracted with $\mathrm{CH}_{2} \mathrm{Cl}_{2}$. The organic layer was dried $\left(\mathrm{Na}_{2} \mathrm{SO}_{4}\right)$ and the solvent was removed in vacuo. Column chromatography on silica $($ EtOAc/hexanes $=2 / 3)$ resulted in clean separation of the two isomers (5) and (7). Yield for (5): $0.30 \mathrm{~g} \mathrm{(26 \% );}{ }^{1} \mathrm{H} \mathrm{NMR}\left(300 \mathrm{MHz}, \mathrm{CDCl}_{3}\right) \delta 7.21$ (bs, $4 \mathrm{H}, \mathrm{N}-\mathrm{H}), 6.85-6.82$ (m, 4H, Ar-H), 6.70-6.66 (m, 4H, Ar-H), 5.92-5.90 (m, 4H, $\beta$-pyrrole-H), 5.63-5.61 (m, 4H, $\beta$-pyrrole-H), 4.68 (bs, 2H, OH), 1.87 (s, 6H, CH $), 1.61$ (s, 6H, $\left.\mathrm{CH}_{3}\right), 1.52$ (s, $6 \mathrm{H}, \mathrm{CH}_{3}$ ); Yield for (7): $0.023 \mathrm{~g}(2 \%) ;{ }^{1} \mathrm{H} \mathrm{NMR}(300 \mathrm{MHz}$, DMSO-d $\left.d_{6}\right) \delta 9.54$ (bs, 4H, pyrrole-NH), 9.18 (bs, 2H, OH), 6.94-6.91 (m, 4H, Ar-H), 6.61-6.58 (m, 4H, Ar-H), 5.70-5.68 (m, 8H, $\beta$-pyrrole-H), 1.72 (s, 6H, $\left.\mathrm{CH}_{3}\right), 1.50$ (s, 12H, $\left.\mathrm{CH}_{3}\right)$.

5,15-(3-Hydroxyphenyl)-5,10,10,15,20,20-hexamethylcalix [4]pymole (6) and (8). To the mixture of (4) (0.31g, 1.2 $\mathrm{mmol})$, acetone $(125 \mathrm{~mL})$ wa added $\mathrm{BF}_{3} \cdot \mathrm{OEt}_{2}(0.3 \mathrm{~mL}, 2.4$ $\mathrm{mmol}$ ) and the whole mixture was stirred for $1 \mathrm{hr}$ at room temperature. Then, the mixture was combined with triethyl amine $(0.7 \mathrm{~mL})$ and the solvent was removed in vacuo. The residue was combined with water and extracted with $\mathrm{CH}_{2} \mathrm{Cl}_{2}(50 \mathrm{~mL} \times$ $3)$. The organic layer was dried $\left(\mathrm{Na}_{2} \mathrm{SO}_{4}\right)$ and the solvent was removed in vacuo. The resulting yellow solid was purified by repeated column chromatography on silica $\left(\mathrm{CH}_{2} \mathrm{Cl}_{2} / \mathrm{EtOAc}=9 / 1\right.$, then EtOAc/hexanes $=2 / 3)$ to afford $(\mathbf{6})$ and $(\mathbf{8})$. Yield for $(\mathbf{6})$ : $0.069 \mathrm{~g}(19 \%) ;{ }^{1} \mathrm{H}$ NMR (300 MHz, DMSO-d $) \delta 9.61$ (bs, 4H, pyrrole-NH), 9.21 (bs, 2H, OH), $7.02(\mathrm{t}, J=7.89 \mathrm{~Hz}, 2 \mathrm{H}, \mathrm{Ar}-\mathrm{H})$, 6.57-6.54 (m, 2H, Ar-H), 6.34 (m, 2H, Ar-H), 6.30-6.27 (m, 2H, Ar-H), 5.72-5.70 (m, 4H, $\beta$-pyrrole-H), 5.63-5.61 (m, 4H, $\beta$-pyrrole-H), $1.76\left(\mathrm{~s}, 6 \mathrm{H}, \mathrm{CH}_{3}\right), 1.63\left(\mathrm{~s}, 6 \mathrm{H}, \mathrm{CH}_{3}\right), 1.50\left(\mathrm{~s}, 6 \mathrm{H}, \mathrm{CH}_{3}\right)$;
MALDI-TOF calcd. for $\mathrm{C}_{38} \mathrm{H}_{40} \mathrm{~N}_{4} \mathrm{O}_{2} 584.32$, found 585.30 $\left(\mathrm{MH}^{+}\right)$; Yield for (8): $0.055 \mathrm{~g}(15 \%) ;{ }^{1} \mathrm{H}$ NMR $(300 \mathrm{MHz}$, $\left.\mathrm{CDCl}_{3}\right) \delta 7.16$ (bs, 4H, pyrrole-NH), $7.13(\mathrm{t}, 2 \mathrm{H}, \mathrm{Ar}-\mathrm{H}), 6.72-$ $6.68(\mathrm{~m}, 4 \mathrm{H}, \mathrm{Ar}-\mathrm{H}), 6.58-6.57(\mathrm{~m}, 2 \mathrm{H}, \mathrm{Ar}-\mathrm{H}), 5.92(\mathrm{t}, 4 \mathrm{H}, \beta-$ pyrrole-H), $5.78(\mathrm{t}, 4 \mathrm{H}, \beta$-pyrrole $-\mathrm{H}), 4.60(\mathrm{~s}, 2 \mathrm{H}, \mathrm{OH}), 1.88(\mathrm{~s}$, $\left.6 \mathrm{H}, \mathrm{CH}_{3}\right), 1.52\left(\mathrm{~s}, 12 \mathrm{H}, \mathrm{CH}_{3}\right)$.

$\mathrm{N}$-Chloroacetyl-pyrenemethylamine (9). The mixture of 1pyrenemethylamine hydrochloride $(0.50 \mathrm{~g}, 1.9 \mathrm{mmol}), \mathrm{K}_{2} \mathrm{CO}_{3}$ (2.6 g, $19 \mathrm{mmol})$, water $(2 \mathrm{~mL})$ and EtOAc $(8 \mathrm{~mL})$ was stirred for $10 \mathrm{~min}$ at room temperature. Then, chloroacetylchloride $(0.25$ $\mathrm{mL}, 3.1 \mathrm{mmol}$ ) was added and the mixture was stirred for $12 \mathrm{hr}$. The mixture was then combined with water and extracted with $\mathrm{CH}_{2} \mathrm{Cl}_{2}$. The organic layer was dried (anhydrous $\mathrm{Na}_{2} \mathrm{SO}_{4}$ ) and the solvent was removed in vacuo. Resulting solid was purified by column chromatography on silica $\left(\mathrm{CH}_{2} \mathrm{Cl}_{2} / \mathrm{EtOAc}=9 / 1\right)$. Yield: $0.32 \mathrm{~g}(56 \%)$; ${ }^{\mathrm{l}} \mathrm{H}$ NMR $\left(300 \mathrm{MHz}, \mathrm{CDCl}_{3}\right) \delta 8.27-7.98$ (m, 9H, pyrene-H), 6.92 (bs, 1H, NH), 5.23 (d, J=5.45 Hz, 2H, $\left.\mathrm{CH}_{2} \mathrm{NH}\right), 4.16\left(\mathrm{~s}, 2 \mathrm{H}, \mathrm{CH}_{2} \mathrm{Cl}\right)$.

Calix [4]pyrmole (10). The mixture of $(5)(0.1 \mathrm{~g}, 0.17 \mathrm{mmol})$, compound (9) (0.14 g, $0.44 \mathrm{mmol}), \mathrm{K}_{2} \mathrm{CO}_{3}(0.53 \mathrm{~g}$, mol), NaI $(0.040 \mathrm{~g}, \mathrm{~mol})$ and acetonitrile $(40 \mathrm{~mL})$ was refluxed for $24 \mathrm{hr}$ under nitrogen atmosphere. Then, the mixture was combined with water and extracted with $\mathrm{CH}_{2} \mathrm{Cl}_{2}(50 \mathrm{~mL} \times 3)$. The organic layer was dried $\left(\mathrm{Na}_{2} \mathrm{SO}_{4}\right)$ and the solvent was removed in vacuo. Column chromatography on silica (EtOAc/hexanes = 1/1) afforded desired compound (10). Yield : $0.024 \mathrm{~g}(12 \%) ;{ }^{1} \mathrm{HNMR}$ $\left(300 \mathrm{MHz}, \mathrm{CDCl}_{3}\right) \delta 8.26-7.94(\mathrm{~m}, 18 \mathrm{H}$, pyrene-H), $7.18(\mathrm{br}$, $4 \mathrm{H}$, pyrrole-NH), 6.94 (br s, 2H, NH), 6.84-6.81 (m, 4H, Ar-H), 6.71-6.68 (m, 4H, Ar-H), 5.85 (t, $J=2.99 \mathrm{~Hz}, 4 \mathrm{H}, \beta$-pyrrole-H), $5.52(\mathrm{t}, J=2.97 \mathrm{~Hz}, 4 \mathrm{H}, \beta$-pyrrole-H), 5.25 (d, $J=5.54 \mathrm{~Hz}, 4 \mathrm{H}$, $\left.\mathrm{CH}_{2} \mathrm{NH}\right), 4.56\left(\mathrm{~s}, 4 \mathrm{H}, \mathrm{CH}_{2} \mathrm{CO}\right), 1.78\left(\mathrm{~s}, 6 \mathrm{H}, \mathrm{CH}_{3}\right), 1.47$ (s, 6H, $\left.\mathrm{CH}_{3}\right), 1.25\left(\mathrm{~s}, 6 \mathrm{H}, \mathrm{CH}_{3}\right)$.

Calix[4]pymole (11). The mixture of (6) $(0.036 \mathrm{~g}, 0.061$ mmol), compound (9) (0.045 g, $0.15 \mathrm{mmol}), \mathrm{K}_{2} \mathrm{CO}_{3}(0.17 \mathrm{~g})$, $\mathrm{NaI}(0.018 \mathrm{~g})$ and acetonitrile $(20 \mathrm{~mL})$ was stirred for $24 \mathrm{hr}$ at room temperature. The mixture was then combined with water and extracted with $\mathrm{CH}_{2} \mathrm{Cl}_{2}(60 \mathrm{~mL} \times 3)$. The organic layer was dried $\left(\mathrm{Na}_{2} \mathrm{SO}_{4}\right)$ and the solvent was removed in vacuo. The resulting yellow solid was purified by column chromatography on silica $\left(\mathrm{CH}_{2} \mathrm{Cl}_{2} / \mathrm{EtOAc}=4 / 1\right)$ to afford (11). Yield $0.033 \mathrm{~g}$ (48\%); ${ }^{1} \mathrm{H}$ NMR $\left(300 \mathrm{MHz}, \mathrm{CDCl}_{3}\right) \delta 8.26-7.95(\mathrm{~m}, 18 \mathrm{H}$, pyrene-H), 7.09 (t, $J=8.08 \mathrm{~Hz}, 2 \mathrm{H}, \mathrm{Ar}-\mathrm{H}), 7.07$ (bs, 4H, pyrrole-NH), 6.91-6.88 (m, 2H, NH), 6.67 (q, $J=8.12 \mathrm{~Hz}, 2 \mathrm{H}, \mathrm{Ar}-$ $\mathrm{H}), 6.56(\mathrm{~d}, J=8.61 \mathrm{~Hz}, 2 \mathrm{H}, \mathrm{Ar}-\mathrm{H}), 6.40-6.39$ (m, 2H, Ar-H), $5.73(\mathrm{t}, J=2.98 \mathrm{~Hz}, 4 \mathrm{H}, \beta$-pyrrole-H), $5.46(\mathrm{t}, J=2.89 \mathrm{~Hz}, 4 \mathrm{H}$, $\beta$-pyrrole-H), 5.24 (d, $\left.J=5.48 \mathrm{~Hz}, 4 \mathrm{H}, \mathrm{CH}_{2} \mathrm{NH}\right), 4.48(\mathrm{~s}, 4 \mathrm{H}$, $\mathrm{CH}_{2} \mathrm{CO}$ ), 1.75 (s, $\left.6 \mathrm{H}, \mathrm{CH}_{3}\right), 1.45\left(\mathrm{~s}, 6 \mathrm{H}, \mathrm{CH}_{3}\right), 1.27$ (s, $\left.6 \mathrm{H}, \mathrm{CH}_{3}\right)$; MALDI-TOF calcd. for $\mathrm{C}_{76} \mathrm{H}_{66} \mathrm{~N}_{6} \mathrm{O}_{4}$ 1126.51, found 1126.52 $\left(\mathrm{M}^{+}\right)$.

Acknowledgments. This work was supported by NRF grant funded by the Korean government [MEST] (2009-0087013). The Central Instrumentation Facility at KNU is acknowledged for support.

\section{References}

1. Gopalan, A.; Zincircioglu, O.; Smith, P. Radioactive Waste Management and Environmental Restoration 1993, 17, 161. 
2. Brim, H.; McFarlan, S. C.; Fredrickson, J. K.; Minton, K. W.; Zhai, M.; Wackett, L. P.; Daly, M. J. Nature Biotechnology 2000, 18, 85.

3. Sessler, J. L.; Gale, P. A.; Cho, W. S. Synthetic Anion Receptor Chemistry; Royal Society of Chemistry: Cambridge, 2006.

4. Chakrabarti, P. J. Mol. Biol. 1993, 234, 463.

5. Van Kuijck, M. A.; Van Aubel, R. A. M. H.; Busch, A. E.; Lang, F.; Russel, G. M.; Bindels, R. J. M.; Van Os, C. H.; Deen, P. M. T. Proc. Natl. Acad. Sci. US A 1996, 93, 5401.

6. Calnan, B. J.; Tidor, B.; Biancalana, S.; Hudson, D.; Frankel, A. D. Science 1991, 252, 1167.

7. Gale, P. A.; Sessler, J. L.; Kràl, V.; Lynch, V. M. J. Am. Chem. Soc. 1996, 118,5140

8. Miyaji, H.; Sato, W.; Sessler, J. L. Angew. Chem. Int. Ed. 2000, 39, 1777.

9. Sessler, J. L.; Gale, P. A.; Genge, J. W. Chem. Eur. J. 1998, 4, 1095.

10. Levitskaia, T. G.; Marquez, M.; Sessler, J. L.; Shriver, J. A.; Vercouter, T.; Moyer, B. A. Chem. Comm. 2003, 2248.

11. Nielsen, K. A.; Cho, W.-S.; Sarova, G. H.; Petersen, B. M.; Bond, A. D.; Becher, J.; Jensen, F.; Guldi, D. M.; Sessler, J. L.; Jeppesen, J. O. Angew. Chem. Int. Ed. 2006, 45, 6848.

12. Yoo, J.; Jeoung, E.-H.; Lee, C.-H. Supramolecular Chem. 2009, 21, 164.
13. Hong, S.-J.; Yoo, J.; Kim, S.-H.; Kim, J.-S.; Yoon, J.; Lee, C.-H. Chem. Commun. 2009, 189.

14. Yoon, D.-W.; Hwang, H.; Lee, C.-H. Angew. Chem. Int. Ed. 2002, $41,1757$.

15. Lee, C.-H.; Na, H.-K.; Yoon, D.-W.; Won, D.-H.; Cho, W.-S.; Lynch, V.-M.; Shevchuk, S. V.; Sessler, J. L. J. Am. Chem. Soc. 2003, 125,7301 .

16. Lee, C.-H.; Lee, J.-S.; Na, H.-K.; Yoon, D.-W.; Miyaji, H.; Cho, W. S.; Sessler, J. L. J. Org. Chem. 2005, 70, 2067.

17. Kim, S.-H.; Hong, S.-J.; Yoo, J.; Kim, S.-K.; Sessler, J. L.; Lee, C.-H. Org. Lett. 2009, 11, 3626.

18. Yoon, D.-W.; Gross, D. E.; Lynch, V. M.; Lee, C.-H.; Bennett, P. C.; Sessler, J. L. Chem. Commun. 2009, 1109.

19. Kim, J.-S.; Lee, S.-H.; Lee, J.-Y.; Bartsch, R. A.; Kim, J.-S. J. Am. Chem. Soc. 2004, 126, 16499.

20. Lee, S.-H.; Kim, S.-H.; Kim, S.-K.; Jung, J.-H.; Kim, J.-S. J. Org. Chem. 2005, 70, 9288

21. Kim, S.-H.; Choi, J.-K.; Kim, S.-K.; Sim, W.; Kim, J.-S. Tetrahedron Lett. 2006, 47, 3737.

22. Jin, T.; Ichikawa, K.; Koyama, T. Chem. Commun. 1992, 499.

23. Kim, J.-H.; Hwang, A.-H.; Chang, S.-K. Tetrahedron Lett. 2004, $45,7557$. 